DOI: 10.15276/ETR.01.2020.4

DOI: $10.5281 /$ zenodo.3967371

UDC: 338.482 .2

JEL: C10, C13, C50

\title{
METHODOLOGY OF COMPETITIVENESS ASSESSMENT SERVICES IN THE TOURISM INDUSTRY
}

\section{МЕТОДИКА ОЦІКИ КОНКУРЕНТОСПРОМОЖНОСТІ ПОСЛУГ У ТУРИСТИЧНІЙ ІНДУСТРІЇ}

Vitaliy I. Zakharchenko, Doctor of Economics, Professor

Odessa National Polytechnic University, Odessa, Ukraine ORCID: 0000-0003-2903-2471 E-mail: kafedra@mzeid.in

Tatiana K. Metil, Candidate of Economic Sciences, Associate Professor Izmail State University for the Humanities, Ukraine ORCID: 0000-0002-4553-4343 E-mail: tatanametil@gmail.com

Larysa M. Soroka, Candidate of Economic Sciences, Associate Professor Izmail State University for the Humanities, Ukraine ORCID: 0000-0002-8014-7509

E-mail: soroka.lara55555@gmail.com

Received 15.01.2020

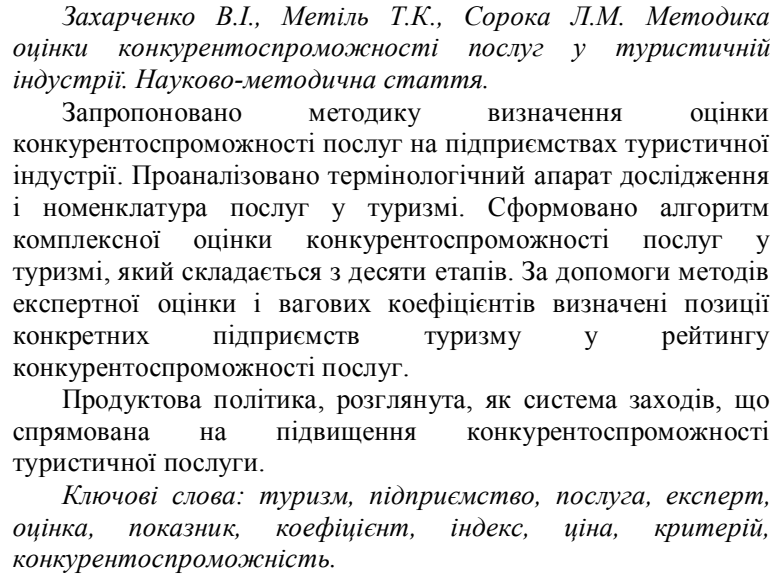

Zakharchenko V.I., Metil T. K., Soroka L.M. Methodology for assessing the competitiveness of services in the tourism industry. Scientific and methodical article.

The method of determining the assessment of the competitiveness of services in the enterprises of the tourism industry is proposed. The terminological apparatus of the research and the nomenclature of services in tourism are analyzed. The algorithm of complex assessment of competitiveness of services in tourism is formed, which consists of ten stages. With the help of expert evaluation methods and weighting factors, the positions of specific tourism enterprises in the rating of competitiveness of services were determined.

Food policy, considered as a system of measures aimed at improving the competitiveness of tourism services.

Keywords: tourism, enterprises, service, expert, evaluation, indicator, coefficient, index, price, criterion, competitiveness.

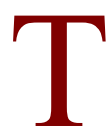

he sphere of services of tourist industry has a significant place in the national economy and in society. The basic direction of this sphere is the maximum satisfaction of human needs not only in high-quality rest, but also in the accompanying services [12].

Modern tourism business is the only economic socio-production system for the development and sale of consumer products in order to meet the market demand for tourism services. There are five phases which can be viewed: development, provision of complexity, realization of consumption, improvement of tourist service.

Ukraine has all objective prerequisites for the intensive development of domestic as well as inbound/outbound tourism. With its favorable geopolitical location, the country has great tourist and recreational potential, favorable climate, rich flora and fauna, world-class cultural and historical monuments and a rapidly developing tourism industry [5, p. 19].

\section{Formulation of the problem}

Today, tourism is the most developed and one of the most dynamic sectors of the world economy. It employs about $10 \%$ of the world's labor resources and produces about 10 of the world's gross output [10].

In the changing conditions of the highly competitive domestic tourist services market, the search for ways to increase its competitiveness, as well as reserves for improving the quality of tourist services, becomes an urgent need for Ukrainian enterprises in the tourism industry. 


\section{Analysis of recent research and publications}

The research of problems of improving the quality and competitiveness of products / services at the micro-level are devoted to the work of such modern researchers as: N. Voskolovich [2], I. Dzhamyshev [3], V. Dubnitsky [6], A. Durovich [4], L. Diadechko [5], V. Kryvorotov [7], D. Smirnova [9], I. Shkoly [10], N. Moiseev [11], I. Udalova [13]. However, in the consideration of specialists, the most attention is paid to the issues of the theoretical nature of the competitiveness of products and much less in the scientific field is the problem of developing a practical methodological support for the assessment of the competitiveness of services. In this context, the work of I. Dzhammysheva [3] aroused interest, although it is devoted to finding a methodological support for the assessment of food competitiveness. Therefore, research on the issues of improving the quality and competitiveness of products / services at the micro-level needs further study.

The scientific article is used general theoretical methods, synthesis and analysis, methods of comparison and analogy, method of expert and point evaluation, tabular, mathematical analysis.

The purpose of the article is to determine a methodical approach to assessing the competitiveness of services of enterprises of the tourist industry of Ukraine and accordingly the strengths and weaknesses of enterprises, reserves of improving the quality of service.

\section{The main part}

In general, the sphere of services is the system of economic activities of the national economy; products whose consumer value is expressed in providing convenience [1, p. 1048]. In the services sector, work does not materialize in things. The process of producing services tends to coincide with their consumption. Distinguish: sphere of services of material production (transport, communication, household service); the sphere of spiritual life services (education, physical culture, tourism, science, art); services in the social sphere (trade, housing and communal services, health care) [10, p. 9].

The peculiarities of the sphere of services of tourist industry are that services which produced and consumed mainly at the same time and are not retained. For this reason, this type of service is based on direct contacts between producers and consumers. Therefore, in the tourism industry there is a certain separation of services from tangible products, the implementation of which is usually associated with the mediation and the possibility of storage [2, 4].

Tourism services are the production of such consumer values, which in the process of activity of the enterprises of the tourist industry do not take material form and satisfy the everyday and aesthetic needs of society.

Attention should be drawn to a more detailed vocabulary definition: tourist services are the result of activity of a tourist enterprise to meet the relevant needs of tourists (sightseers). The basis for the development of travel services is its brief description. This is a set of requirements that are determined by market research that are agreed with the customer and take into account the capabilities of the service provider. The management of the tourism enterprise approves the procedure and procedure for the development of a specific service, the organization of service provision and defines the responsibility of each participant in the process of designing the service. The specific requirements for the tourist service process should be no less than the requirements of the current regulations. The design of the tourist service process is carried out at separate stages of service provision (for example, providing information about the service, providing the service, billing for the service) and developing a technological map for each of them. The content and sequence of stages may vary depending on the type of service. The result of designing a tourist service is technological documents (technological maps, instructions, rules, regulations, etc.) [1, p. 1135].

In a competitive environment, the main objective of the tourism enterprise is to obtain the optimum profit by ensuring the necessary quality of tourist services and reducing the costs of providing services. The overwhelming majority of tourism enterprises, seeking to maximize profits by reducing costs, are deteriorating the quality of tourism services. Assessment of the competitiveness (COP) of the service of the tourism enterprise includes a number of stages that take into account specific features of tourism (Table 1).

Table 1. The algorithm of complex assessment of competitiveness of services in the tourism industry

\begin{tabular}{|c|l|}
\hline Operation number & The content of the operation \\
\hline 1 & $\begin{array}{l}\text { Determination of the list of single, complex and generalized indicators necessary and sufficient to } \\
\text { evaluate the COP of the service }\end{array}$ \\
\hline 2 & Determination of weighting coefficients of all indicators of service COP \\
\hline 3 & Setting basic values for single metrics \\
\hline 4 & Determining the type of dependence between COP indicators and their estimates \\
\hline 5 & Measurement of individual COP indicators or their expert scoring \\
\hline 6 & Calculation of estimates of individual unit and complex indicators of service COP \\
\hline 8 & Determination of the generalized index of COP of tourism services of the compared enterprises \\
\hline 9 & Determination of relative cost of services in the compared enterprises \\
\hline 10 & Calculation of the integral indicator of the COP services of each enterprise \\
\hline
\end{tabular}

Source: compiled by autor on materials [3, p. 93-94]. 
I. In the first stage, a list of single, comprehensive and generalized indicators, necessary and sufficient for the evaluation of the COP of tourism services, is determined.

The aggregate indicator may include a number of integrated indicators of the COP of tourism services: (1) the quality of realized tourism services; (2) rationality of the nomenclature of services; (3) a culture of service; (4) terms of service; (5) availability of the service.

In order to ensure comparative analysis, it is advisable to select travel agencies belonging to one type (tourist industry enterprises classified by defined travel destinations and service levels of the host party) and type (tourism enterprises distinguished by type, classified by type of travel and leisure options) of the tourism industry.

1. The quality of a service (product) can be defined as the total set of technical, technological, operational characteristics of a service, a product by which a service or product will meet the requirements of the consumer during operation [6, p. 76].

2. The rationality of the nomenclature of services is characterized by the following indicators, which reflect the nomenclature: (a) completeness, (b) latitude, (c) stability, (d) novelty, (d) structure, (e) renewal.

(a). Completeness of nomenclature is the ability of a set of homogeneous group services to meet the same needs. Completeness is characterized by the number of types, varieties and names of services of a homogeneous group and can be a valid Пд (actual number of types, varieties and names of services of a homogeneous group) and basic Пб (number of services that are regulated or planned). The coefficient of completeness of the nomenclature (Кп) is determined by the formula:

$$
\kappa n=\Pi \partial / \Pi б,
$$

(b). Width of nomenclature - number of types, varieties and names of homogeneous and heterogeneous services. This property is characterized by two partial indicators - the true Lq (the actual number of types of services provided by the tourism enterprise) and the basic Lb (latitude, which is taken as the basis for comparison, the maximum possible) latitude, as well as the latitude factor. The latitude factor (Кш) can be determined by the formula:

$$
K u=L q / L \sigma \text {, }
$$

(b). Nomenclature stability is the ability of a set of services to meet the demand for one and the same service. The coefficient of stability $(\mathrm{Kc})$ is determined by the formula:

$$
K c=\Pi \sigma / L \sigma,
$$

(d). Nomenclature novelty is the ability of a set of services to meet changing needs through new services. Novelty is characterized by actual updates the number of new services in the general list $(\mathrm{H})$ and the degree of updating $(\mathrm{KH})$, which is reflected by the ratio of the number of new services to the total number of service names (or actual latitude). The coefficient of novelty $\left(\mathrm{K}_{\mathrm{H}}\right)$ is determined by the formula:

$$
K H=H / L q,
$$

(e). The structure of the nomenclature is characterized by the proportion of each type and / or name of the service in the total set. Indicators of the structure of the nomenclature (Ksi) can be calculated in kind and in monetary form. They are calculated as the ratio of the number of individual services $(\mathrm{Ni})$ to the total number of all services:

$$
K s i=N i / \Pi б .
$$

3. Service culture can be defined as an indicator of "skill of the service personnel" [13]. Skill is the ability to take the utmost account of individual customer requests. As a part of this criterion, it is possible to define, through individual indicators: politeness; neatness; attentiveness, ie the ability to draw the consumer's attention to the emergence of a special service, the ability to choose the best option for the tourist product, etc.

4. Terms of service are determined by the following single indicators: material and technical base of the enterprise, the category of the enterprise, convenience for the consumer (convenience of the room for negotiations, registration of information, additional consultations [11].

5. Availability of the service includes the following single cost indicators: amount of money, time to obtain a location certificate, time to wait for service, time to travel to the office of a tourist enterprise, time to deliver documents, time to consult a specialist $[9, \mathrm{p}$. 50-54].

As a rule, the pre-service costs far exceed the time spent by the consumer to contact the tourism worker directly. In a competitive environment, the survival of tourism businesses is possible when the optimal profit is obtained by ensuring the necessary quality of tourist services and reducing the costs of providing services.

II. In the second stage, for the calculation of calculations using the generalized indicators, it is necessary to determine the coefficients of importance of the indicators of the COP of tourism services. An expert group is interviewed for these purposes. The number of qualified experts (more than 13) in the tourism industry (tour operators, employees of travel agencies and companies, teachers of tourism economics of universities) with at least five years' experience is involved as experts in mathematical sampling [8, p. 155-160].

In the expert evaluation of the importance of COP indicators of tourism services, it is advisable to use a scale $(5,10,100$, etc. ) according to the objectives of the study (in our case with an interval of variation of $0.5)$ [ 8 , p. 128-129]. The use of the scoring system is due to the fact that some of the individual indicators (choosing a room in a hotel with a specific landscape or car brand for individual travel) cannot be quantified and the indicators being measured have different 
dimensions. The use of a scoring system allows us to further operate both the results of the measurement is measured and those that cannot be determined.

The weighting factor $\mathrm{Vi}$ is calculated by each $\mathrm{i}$-th indicator and the $\mathrm{j}$-th expert and is calculated by the formula:

$$
V i=\sum_{j=1}^{N} b i j \mid N * B,
$$

where $i$ is the index of the COP index, $i=1, \ldots, n$, $\mathrm{n}$ is the number of indicators,

$\mathrm{j}$ - index of expert number, $\mathrm{j}=1, \ldots, \mathrm{N}$,

bij is the point score of the $\mathrm{j}$-th expert on the $\mathrm{i}$-th indicator,

$\mathrm{N}$ - total number of experts, $\mathrm{N}>13$,
$\mathrm{B}$ is the total number of points.

In this study the task of assessing the COP of the services of tourism enterprises in Odessa was set. When evaluating the quality of tourism services for different nomenclature groups of services, the calculation was complicated due to the fact that it is necessary to take into account the quality and rationality of the nomenclature of services provided in this consumer market. For convenience of calculation a certain group of services was adopted.

The results of the calculation of the average values of the normative coefficients of importance of the COP indicators of tourism services are presented in Table 2, which uses the point of view of 15 experts.

Table 2. Average value of normative coefficients of importance of indicators of competitiveness of services of tourism enterprises

\begin{tabular}{|c|c|c|}
\hline COP indicators (i) & Sum of points (bij) & $\begin{array}{l}\text { Weighting } \\
\text { coefficient (Vi) }\end{array}$ \\
\hline $\begin{array}{l}\text { 1. Quality of services which is provided: } \\
\text { 1.1. Time of presence in the tourist services market } \\
\text { 1.2. Compliance of services with international quality standards. } \\
\text { 1.3. Use of new technologies in the provision of services. } \\
\text { 1.4. Frequency of change of service nomenclature } \\
\text { 1.5. Image of tourism enterprise in the regional tourist services market } \\
\text { 1.6. The level of security for customers. } \\
\text { 1.7. Sustainable growth in sales of services. } \\
\text { 1.8. Level of connection (entry) in international tourism organizations } \\
\text { Final assessment of service quality. }\end{array}$ & $\begin{array}{l}7.5 \\
9.0 \\
7.5 \\
6.0 \\
9.0 \\
10.5 \\
12.0 \\
3.0\end{array}$ & $\begin{array}{l}0.05 \\
0.06 \\
0.05 \\
0.04 \\
0.06 \\
0.07 \\
0.08 \\
0.02 \\
0.43\end{array}$ \\
\hline $\begin{array}{l}\text { 2. Rationality of service nomenclature: } \\
\text { 2.1. Completeness of nomenclature } \\
\text { 2.2. Width of nomenclature } \\
\text { 2.3. Nomenclature stability } \\
\text { 2.4. Novelty of nomenclature } \\
\text { 2.5. Nomenclature structure } \\
\text { Final assessment of the rationality of the nomenclature of services }\end{array}$ & $\begin{array}{l}13.5 \\
12.0 \\
10.5 \\
7.5 \\
4.5\end{array}$ & $\begin{array}{l}0.09 \\
0.08 \\
0.07 \\
0.05 \\
0.03 \\
0.32\end{array}$ \\
\hline $\begin{array}{l}\text { 3. Service culture: } \\
\text { 3.1. Politeness } \\
\text { 3.2. Neatness } \\
\text { 3.3. Attentiveness } \\
\text { Final assessment of service culture } \\
\end{array}$ & $\begin{array}{l}6.0 \\
4.5 \\
1.5\end{array}$ & $\begin{array}{l}0.04 \\
0.03 \\
0.01 \\
0.08 \\
\end{array}$ \\
\hline $\begin{array}{l}\text { 4. Terms of service: } \\
\text { 4.1. Material-technical base } \\
\text { 4.2. Category of enterprise } \\
\text { 4.3. Convenience for consumers } \\
\text { 4.4 Visibility of information presentation } \\
\text { 4.5. Additional advice } \\
\text { Final assessment of service conditions }\end{array}$ & $\begin{array}{l}3.0 \\
1.5 \\
3.0 \\
1.5 \\
1.5\end{array}$ & $\begin{array}{l}0.02 \\
0.01 \\
0.02 \\
0.01 \\
0.01 \\
0.07\end{array}$ \\
\hline $\begin{array}{l}\text { 5. Availability of the service: } \\
\text { 5.1. Cash expenses } \\
\text { 5.2. Spending time getting location help } \\
\text { 5.3. Time-consuming waiting for service } \\
\text { 5.4. Expenses of travel time to the office of the tourist enterprise } \\
\text { 5.5. Expenses of time for delivery of documents } \\
\text { 5.6. spending time on consultation for specialists } \\
\text { Final assessment of service availability }\end{array}$ & $\begin{array}{l}3.0 \\
1.5 \\
1.5 \\
1.5 \\
1.5 \\
6.0\end{array}$ & $\begin{array}{l}0.02 \\
0.01 \\
0.01 \\
0.01 \\
0.01 \\
0.04 \\
0.10\end{array}$ \\
\hline Total result & & 1.00 \\
\hline
\end{tabular}

Source: authors' own development

III. In the third stage, the baseline values of the individual indicators are set in accordance with the requirements of the standards. The normative values of the COP indicators for tourism services are presented in Table 3 . 
Table 3. Regulatory values of COP indicators of services of tourism enterprises

\begin{tabular}{|c|c|}
\hline Competitiveness indicators (Пi) & Normative values \\
\hline \multicolumn{2}{|l|}{ 1. Quality of services which is provided } \\
\hline 1.1. Time of presence in the tourist services market & At least 3 years \\
\hline 1.2. Compliance of services with international quality standards. & $\begin{array}{l}\text { Full compliance with ISO standards - 9000, 9001, } \\
9002,9003\end{array}$ \\
\hline 1.3. Use of new technologies in service delivery. & $\begin{array}{l}\text { At least } 70 \% \text { of the equipment must be fundamentally } \\
\text { new }\end{array}$ \\
\hline 1.4. Frequency of change of service nomenclature & Every year \\
\hline 1.5. Image of the tourism enterprise on the regional & High \\
\hline 1.6. The level of security for customers. & High \\
\hline 1.7. Sustainable growth in sales of services. & $20 \%$ annually \\
\hline $\begin{array}{l}\text { 1.8. Level of connection (entry) in international tourism } \\
\text { organizations }\end{array}$ & Not less than 3 \\
\hline \multicolumn{2}{|l|}{ 2. Rationality of service nomenclature: } \\
\hline 2.1. Completeness of nomenclature & $\begin{array}{l}\text { The actual number of service names corresponds to } \\
\text { the planned number of services of this type }\end{array}$ \\
\hline 2.2. Width of nomenclature & $\begin{array}{l}\text { The actual number of types of services corresponds to } \\
\text { the maximum possible number of services of that } \\
\text { type }\end{array}$ \\
\hline 2.3. Nomenclature stability & $\begin{array}{l}\text { The services provided satisfy the high demand of } \\
\text { consumers }\end{array}$ \\
\hline 2.4. Novelty of nomenclature & $\begin{array}{l}\text { The number of new services corresponds to the total } \\
\text { number of service names }\end{array}$ \\
\hline 2.5. Nomenclature structure & $\begin{array}{l}\text { The high proportion of each type of service in the } \\
\text { total number of service names }\end{array}$ \\
\hline \multicolumn{2}{|l|}{ 3. Service culture: } \\
\hline 3.1. Politeness & Very polite \\
\hline 3.2. Neatness & Managers are very nasty \\
\hline 3.3. Attentiveness & Managers are very careful \\
\hline \multicolumn{2}{|l|}{ 4. Terms of service: } \\
\hline 4.1. Material-technical base & High \\
\hline 4.2. Category of enterprise & Not normalized \\
\hline 4.3. Convenience for consumers & Enough \\
\hline 4.4 Visibility of information presentation & Widely used \\
\hline 4.5. Additional advice & At a high level \\
\hline \multicolumn{2}{|l|}{ 5. Availability of the service: } \\
\hline 5.1. Cash expenses & Minor \\
\hline 5.2. Spending time getting location help & Minor \\
\hline 5.3. Time-consuming waiting for service & Minor \\
\hline 5.4. Expenses of travel time to the office of the tourist enterprise & Minor \\
\hline 5.5. Expenses of time for delivery of documents & Minor \\
\hline 5.6. Spending time on consultation for specialists & Minor \\
\hline
\end{tabular}

Source: authors' own development

IV. The fourth stage is determined the type of relationship between the COP indicators and their estimates.Generalized criterion of COP of tourism services of KK can be determined by the formula:

$$
K_{\mathrm{y}}=K_{\mathrm{g}}+\mathrm{K}_{\mathrm{p}}+\mathrm{K}_{\mathrm{K}}+\mathrm{K}_{\mathrm{o}}+\mathrm{K}_{\text {д }}
$$

where $K_{\mathrm{r}}$ - the complex criterion of the quality of service is realized and determined by the formula:

$$
\mathrm{K}_{\mathrm{g}}=\sum_{\mathrm{i}=1}^{\mathrm{n}} \mathrm{b}_{\mathrm{gi}} * \mathrm{~V}_{\mathrm{gi}} \text {, }
$$

where $i$ is the index of the COP, $i=1, \ldots, n$,

$\mathrm{n}$ is the number of indicators,

$b_{\text {gi }}$ - a point evaluation of a single indicator of the quality of services being implemented,
$K_{p}$ - comprehensive indicator of the COP rationality of the nomenclature of services and is determined by the formula:

$$
\mathrm{K}_{\mathrm{p}}=\sum_{\mathrm{i}=1}^{\mathrm{n}} \mathrm{b}_{\mathrm{pi}} * \mathrm{~V}_{\mathrm{pi}}
$$

where $b_{p i}$ is a point estimate of a single indicator of service nomenclature rationality,

$\mathrm{V}_{\mathrm{pi}}$ - coefficient of weight of a single indicator of the rationality of the nomenclature of services,

$\mathrm{K}_{\mathrm{k}}$ - comprehensive indicator of the COP of the culture of service and is determined by the formula:

$$
\mathrm{K}_{\mathrm{k}}=\sum_{\mathrm{i}=1}^{\mathrm{n}} \mathrm{b}_{\mathrm{pi}} * \mathrm{~V}_{\mathrm{Ki}}
$$

where $b_{p i}$ is a point estimate of a single service culture indicator, 
$\mathrm{V}_{\mathrm{Ki}}$ is the weighting factor of a single service culture indicator,

$\mathrm{K}_{\mathrm{O}}$ - complex indicator of the COP of service conditions and is determined by the formula:

$$
\mathrm{K}_{\mathrm{o}}=\sum_{\mathrm{i}=1}^{\mathrm{n}} \mathrm{b}_{\mathrm{oi}} * \mathrm{~V}_{\mathrm{oi}},
$$

where $b_{o i}$ is a point estimate of a single indicator of service conditions,

$\mathrm{V}_{\mathrm{oi}}$ is the weighting factor of a single service culture indicator,
$\mathrm{K}_{\mathrm{d}}$ - complex indicator of service availability $\mathrm{COP}$ and is determined by the formula:

$$
\mathrm{K}_{\mathrm{d}}=\sum_{\mathrm{i}=1}^{\mathrm{n}} \mathrm{b}_{\mathrm{di}} * \mathrm{~V}_{\mathrm{di}},
$$

where $b_{d i}$ is a point estimate of a single service availability indicator,

$\mathrm{V}_{\mathrm{di}}$ is the weighting factor of a single service availability indicator.

$\mathrm{V}$. In the fifth stage, the individual indicators of the COP are measured, that is, their point expert evaluation is determined (Table 4).

\begin{tabular}{|c|c|c|c|c|}
\hline \multirow{2}{*}{ Complex Indicator } & \multirow{2}{*}{ Single Indicator } & \multicolumn{3}{|c|}{ Graduation of point scores } \\
\hline & & Good-4 & Satisfactory-3 & Unsatisfactory-2 \\
\hline 1 & 2 & 3 & 4 & 5 \\
\hline \multirow{9}{*}{$\begin{array}{l}\text { 1. The quality of the } \\
\text { service which is } \\
\text { provided }\end{array}$} & $\begin{array}{l}\text { 1.1. Time of presence in } \\
\text { the tourist services } \\
\text { market }\end{array}$ & More than 5 years & $3-5$ years & Less than 3 years \\
\hline & $\begin{array}{lr}1.2 . \quad \text { Compliance } & \text { of } \\
\text { services } & \text { with } \\
\text { international } & \text { quality } \\
\text { standards. }\end{array}$ & Complete & In most cases & Partially \\
\hline & $\begin{array}{l}\text { 1.3. Use of new } \\
\text { technologies in service } \\
\text { delivery. }\end{array}$ & $\begin{array}{l}\text { Only new } \\
\text { technologies }\end{array}$ & In most cases & Partially \\
\hline & $\begin{array}{lc}1.4 . \quad \text { Frequency } & \text { of } \\
\text { nomenclature change }\end{array}$ & Regular & In most & From time to time \\
\hline & Of services & & cases & \\
\hline & $\begin{array}{l}\text { 1.5. Image of the tourism } \\
\text { enterprise on the regional }\end{array}$ & High & Average & Low \\
\hline & $\begin{array}{l}\text { 1.6. The level of security } \\
\text { for customers. }\end{array}$ & High & Average & Low \\
\hline & $\begin{array}{l}\text { 1.7. Sustainable growth } \\
\text { in sales of services. }\end{array}$ & Continuous growth & Constant & Fall \\
\hline & $\begin{array}{l}\text { 1.8. Level of connection } \\
\text { (entry) in international }\end{array}$ & Constantly & From time to time & Missing \\
\hline \multirow{5}{*}{$\begin{array}{l}\text { 2. Rationality of } \\
\text { service nomenclature: }\end{array}$} & $\begin{array}{l}\text { 2.1. Completeness of } \\
\text { nomenclature }\end{array}$ & 1,0 & $0,8-0,9$ & Below 0.8 \\
\hline & $\begin{array}{ll}2.2 . \quad \text { Width } & \text { of } \\
\text { nomenclature }\end{array}$ & 1,0 & $0,8-0,9$ & Below 0.8 \\
\hline & $\begin{array}{ll}2.3 . & \text { Nomenclature } \\
\text { stability } & \\
\end{array}$ & 1,0 & $0,8-0,9$ & Below 0.8 \\
\hline & $\begin{array}{lll}2.4 . \quad \text { Novelty of } \\
\text { nomenclature }\end{array}$ & 1,0 & $0,8-0,9$ & Below 0.8 \\
\hline & $\begin{array}{ll}2.5 . & \text { Nomenclature } \\
\text { structure } & \\
\end{array}$ & 1,0 & $0,8-0,9$ & Below 0.8 \\
\hline \multirow{3}{*}{ 3. Service culture: } & 3.1. Politeness & Very polite & Not polite enough & Involuntary \\
\hline & 3.2. Neatness & $\begin{array}{c}\text { Managers are very } \\
\text { nasty }\end{array}$ & $\begin{array}{l}\text { Managers are not } \\
\text { well drained }\end{array}$ & $\begin{array}{c}\text { Managers are } \\
\text { sloppy }\end{array}$ \\
\hline & 3.3. Attentiveness & $\begin{array}{l}\text { Managers are very } \\
\text { attentive }\end{array}$ & $\begin{array}{c}\text { Managers are not } \\
\text { careful enough }\end{array}$ & $\begin{array}{l}\text { Managers are } \\
\text { inattentive }\end{array}$ \\
\hline \multirow{5}{*}{ 4. Terms of service } & $\begin{array}{l}\text { 4.1. Material-technical } \\
\text { base }\end{array}$ & High & Medium & Low \\
\hline & $\begin{array}{lll}4.2 . \quad \text { Category } & \text { of } \\
\text { enterprise } & & \\
\end{array}$ & 1 & 2 & 3 \\
\hline & $\begin{array}{ll}\begin{array}{l}\text { 4.3. Convenience for } \\
\text { consumers }\end{array} & \\
\end{array}$ & Enough & Preferably better & Not enough \\
\hline & $\begin{array}{l}4.4 \quad \text { Visibility of } \\
\text { information presentation }\end{array}$ & Enough & Preferably better & Not enough \\
\hline & 4.5. Additional advice & At a high level & Not enough & Not enough \\
\hline
\end{tabular}

Table 4. Point evaluation of the competitiveness of tourism services and the criteria for their evaluation 
Continuation of Table 4.

\begin{tabular}{|c|c|c|c|c|}
\hline 1 & 2 & 3 & 4 & 5 \\
\hline \multirow{6}{*}{ 5. Service availability } & 5.1. Cash expenses & Minor & Medium & High \\
\hline & $\begin{array}{l}\text { 5.2. Spending time } \\
\text { getting location help }\end{array}$ & Minor & Medium & High \\
\hline & $\begin{array}{l}5.3 . \quad \text { Time-consuming } \\
\text { waiting for service }\end{array}$ & Minor & Medium & High \\
\hline & $\begin{array}{l}\text { 5.4. Expenses of travel } \\
\text { time to the office of the } \\
\text { tourist enterprise }\end{array}$ & Minor & Medium & High \\
\hline & $\begin{array}{l}\text { 5.5. Expenses of time for } \\
\text { delivery of documents }\end{array}$ & Minor & Medium & High \\
\hline & $\begin{array}{l}\text { 5.6. Spending time on } \\
\text { consultation } \\
\text { specialists }\end{array}$ & Minor & Medium & High \\
\hline
\end{tabular}

Source: authors' own development

VI. In the sixth stage, it is necessary to calculate individual single and integrated indicators of $\mathrm{COP}$ of tourism services. For the purposes of the study, three enterprises of the tourism industry of Odessa were selected in the study: TOV «Alvona - Planet» (T1), PP «Modes» (T2), TOV «Fagot Travel Plus» (T3) (Table 5).
From Table 5 it can be seen that the service quality indicators of different enterprises are approximately the same. This is due to the fact that the market under study is sufficiently saturated and segmented.

Table 5. Value of tourism competitiveness indicators

\begin{tabular}{|c|c|c|c|}
\hline \multirow{2}{*}{ Indicators } & \multicolumn{3}{|c|}{ Research results } \\
\hline & $\mathrm{T} 1$ & $\mathrm{~T} 2$ & T3 \\
\hline $\begin{array}{l}\text { 1.1. Time of presence in the tourist services } \\
\text { market }\end{array}$ & 1,0 & 1,0 & 1,0 \\
\hline $\begin{array}{l}\text { 1.2. Compliance of services with international } \\
\text { quality standards. }\end{array}$ & 0,8 & 0,8 & 0,8 \\
\hline $\begin{array}{l}\text { 1.3. Use of new technologies in service } \\
\text { delivery. }\end{array}$ & 0,8 & 0,8 & 0,8 \\
\hline $\begin{array}{l}\text { 1.4. Frequency of change of service } \\
\text { nomenclature }\end{array}$ & 0,7 & 0,7 & 0,7 \\
\hline $\begin{array}{l}\text { 1.5. Image of the tourism enterprise on the } \\
\text { regional }\end{array}$ & 1,0 & 1,0 & 1,0 \\
\hline 1.6. The level of security for customers. & 0,9 & 0,9 & 0,9 \\
\hline 1.7. Sustainable growth in sales of services. & 0,7 & 0,7 & 0,7 \\
\hline $\begin{array}{l}\text { 1.8. Level of connection (entry) in } \\
\text { international }\end{array}$ & 0,6 & 0,6 & 0,7 \\
\hline 2.1. Completeness of nomenclature & 1,0 & 0,9 & 1,0 \\
\hline 2.2. Width of nomenclature & 1,0 & 0,9 & 1,0 \\
\hline 2.3. Nomenclature stability & 1,0 & 1,0 & 0,9 \\
\hline 2.4. Novelty of nomenclature & 1,0 & 0,9 & 0,8 \\
\hline 2.5. Nomenclature structure & 1,0 & 0,8 & 0,8 \\
\hline 3.1. Politeness & Very polite & Not polite enough & Not polite enough \\
\hline 3.2. Neatness & Very prim & Not very prim & Not very prim \\
\hline 3.3. Attentiveness & Very attentive & Not very attentive & Not very attentive \\
\hline 4.1. Material-technical base & High & Medium & Medium \\
\hline 4.2. Category of enterprise & 1 & 2 & 1 \\
\hline 4.3. Convenience for consumers & Enough & Preferably better & Preferably better \\
\hline 4.4 Visibility of information presentation & Enough & Preferably better & Preferably better \\
\hline 4.5. Additional advice & Not implemented & Not implemented & Not implemented \\
\hline 5.1. Cash expenses & Minor & Minor & Minor \\
\hline 5.2. Spending time getting location help & Minor & Minor & Minor \\
\hline 5.3. Time-consuming waiting for service & Minor & Medium & Minor \\
\hline $\begin{array}{l}\text { 5.4. Expenses of travel time to the office of the } \\
\text { tourist enterprise }\end{array}$ & Minor & Minor & High \\
\hline $\begin{array}{l}\text { 5.5. Expenses of time for delivery of } \\
\text { documents }\end{array}$ & Minor & Minor & Minor \\
\hline $\begin{array}{l}\text { 5.6. Spending time on consultation for } \\
\text { specialists }\end{array}$ & Missing & Missing & Missing \\
\hline
\end{tabular}

Source: authors' own development 
The next step is to translate the value of the single and comprehensive indicators of the tourism services COP into points and calculate the individual indicators of the services COP. For this purpose, an expert group of 15 experts evaluated the COP of tourism services from five groups of indicators with the assignment of services exploring specific absolute values of indicators having different dimensions. And in accordance with table 4, they were translated into points (table 6).

Table 6. Results of calculations of single indicators of competitiveness services of tourism enterprises

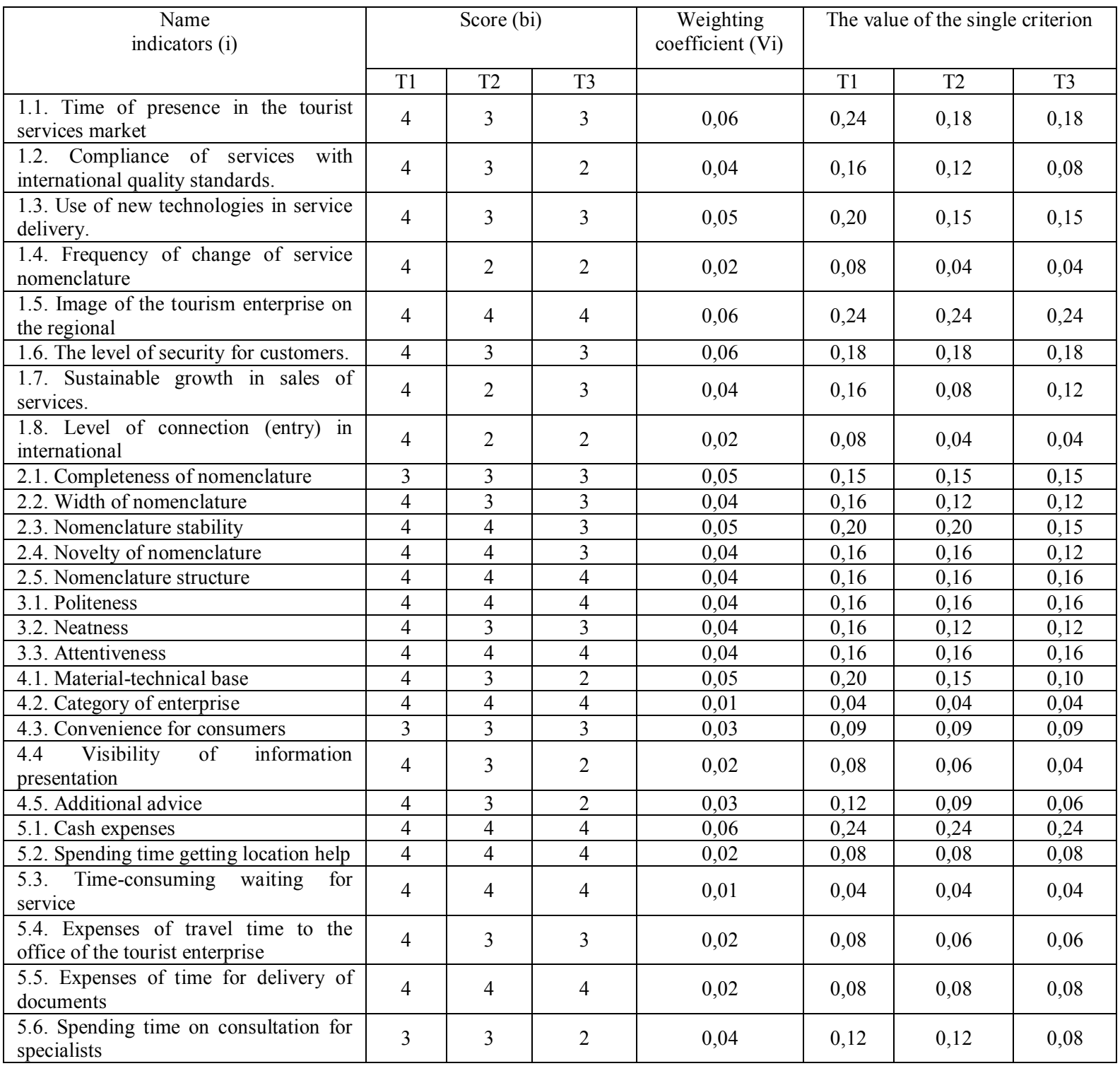

Source: authors' own calculations.

Complex criteria of quality of services provided by COP are calculated by the formula (8) and make the following values for enterprises: $\mathrm{T} 1-\mathrm{Kr}=1,34$; $\mathrm{T} 2-\mathrm{Kr}=1,03 ; \mathrm{T} 3-\mathrm{Kr}=1,03$.

Complex indicators of the COP of the rationality of the service nomenclature are calculated by the formula (9) and are: $\mathrm{T} 1-\mathrm{Kr}=0,83 ; \mathrm{T} 2-\mathrm{Kp}=0,79$; $\mathrm{T} 3-\mathrm{Kp}=0,70$.

Complex indicators of COP of service culture are calculated by the formula (10) and are: T1 $-\mathrm{K \kappa}=$ 0,$48 ; \mathrm{T} 2-\mathrm{K} \kappa=0,44 ; \mathrm{T} 3-\mathrm{K} \kappa=0,44$. The complex indicators of the COP of the service conditions are calculated by the formula (11) and are: $\mathrm{T} 1-\mathrm{Ko}=$ 0,$53 ; \mathrm{T} 2-\mathrm{Ko}=0,43 ; \mathrm{T} 3-\mathrm{Ko}=0,33$.

Complex indicators of service availability COP are calculated by the formula (12) and are: $\mathrm{T} 1-\mathrm{Kg}=$ 0,64; $\mathrm{T} 2-\mathrm{Kg}=0,62 ; \mathrm{T} 3-\mathrm{Kg}=0,58$.

VII. In the next stage, we calculate the generalized criteria of the $\mathrm{CC}$ of tourism services of the $\mathrm{CC}$ according to the formula (7). The generalized indicator of the quality of tourism service allows only an average estimate of the level of COP of the service, since not all the types of services are being taken into account, as well as their relative cost.

VIII. In the eighth stage the relative price of the service is determined. To do this, each company needs to determine the list of services that are included in the nomenclature of all three enterprises, and to calculate individual price indices. 
Individual price indices are determined by the formula:

$$
\mathrm{I}_{\mathrm{p}}=\mathrm{P}_{\phi} / \mathrm{P}_{\sigma}
$$

where $I_{p}$ is the individual price index of a particular name of $\mathrm{m}$ services,
$\mathrm{P}_{\phi}$ - the actual value of the service of a certain type,

$\mathrm{P}_{6}$ - the lowest value of the service of a certain name, which is perceived as a base for comparison.

The results of the price index calculations are shown in Table 7.

Table 7. Calculation of average price index for tourism enterprises

\begin{tabular}{|l|l|l|l|}
\hline Name enterprises & $\begin{array}{l}\text { Service price, thousand UAH. } \\
\left(\mathrm{P}_{\phi}\right)\end{array}$ & Individual price indices $\left(\mathrm{I}_{\mathrm{p}}\right)$ & $\begin{array}{l}\text { Average price indices } \\
\left(\mathrm{I}_{\mathrm{p} p}\right)\end{array}$ \\
\hline TOV “Alvona - Planet” & 6,75 & 1,$29 ; 1,13 ; 1,15$ & 1,13 \\
\hline PP "Modes" & 7,29 & 1,$13 ; 1,14 ; 1,12$ & 1,13 \\
\hline TOV "Fagot Travel Plus" & 6,75 & 1,$13 ; 1,15 ; 1,12$ & 1,13 \\
\hline
\end{tabular}

Source: authors' own development

The average price index in Table 7 for each enterprise is calculated by the formula:

$$
\mathrm{I}_{\mathrm{cp}}=\left(\sum_{t=1}^{t=3} * I_{p}\right) / 3 .
$$

IX. In the ninth stage, the integral value of service COP for each enterprise is determined by the formula:

$$
\mathrm{KK}_{\mathrm{iHT}}=\mathrm{K}_{\mathrm{y}} / \mathrm{I}_{\mathrm{cp}},
$$

where $K_{y}$ is a generalized criterion for the COP of tourism services,

$\mathrm{I}_{\mathrm{cp}}-$ the average price index of services.

The results of the evaluation of the COP of services at the enterprises under study are shown in Table 8. (Methodological support for the integrated assessment of the level of competitiveness of the enterprise can also be seen in other studies [7, p. 270274].)

Table 8. Calculation of integrated competitiveness indicator services for tourism enterprises

\begin{tabular}{|l|l|l|l|}
\hline Name of tourism enterprise & Generalized indicator $\left(\mathrm{KK}_{\mathrm{y}}\right)$ & $\begin{array}{l}\text { Average Price Index } \\
\left(\mathrm{I}_{\mathrm{cp}}\right)\end{array}$ & $\begin{array}{l}\text { An integral indicator } \\
\text { of competitiveness } \\
\left(\mathrm{KK}_{\mathrm{iнт}}\right)\end{array}$ \\
\hline TOV «Alvona - Planet» & 3,82 & 1,13 & 3,38 \\
\hline PP «Modes» & 3,31 & 1,13 & 2,93 \\
\hline TOV «Fagot Travel Plus» & 3,08 & 1,13 & 2,73 \\
\hline
\end{tabular}

Source: authors' own development

$X$. At the tenth stage, it is necessary to conclude on the position in the rating of the COP of tourism services, identify their strengths and weaknesses, as well as reserves for improving the quality of tourism services.

\section{Conclusions}

Thus, the conducted researches made it possible to establish that the T1 company occupies the first place in the rating of tourist services COP. At the same time, it is important for him to systematically innovate in his services. Enterprise T2 is the second place, but it is necessary to focus its activities on the systematic improvement of the culture of service, ensuring the stability of the nomenclature, improving the material and technical base and accessibility of services. Enterprise T3 - third place; this is due to the poor quality of the services being provided and the culture, conditions and availability of services.

As a final conclusion, it is possible to emphasize the following: virtually all serious marketing successes of tourism enterprises are based on the use of their best forces against the weaknesses of competitors. This gives the tourism business enterprise: individual market advantages and the ability of scientifically grounded positions with mandatory preplanned research to evaluate the likely prospects of market advantages; identify specific priorities urgently; take appropriate competitive intelligence measures and ensure their securityoriented development through the development of a strategy of neutralization in the market of strong characteristics of competitors' tourism services; in qualitative terms to increase the competitiveness of a particular type of services and the efficiency of the enterprise as a whole; analyzing information about competitors, carry out systematic work to improve the motivation and skills of the staff of the tourism company. This is not a complete list of proposals that contribute to the dynamic development of tourism enterprises, a consistent increase in the volume and quality of tourism services without involving the state. Despite the financial, economic and sociopolitical difficulties of recent years, the tourism industry of Ukraine is trying to consistently increase the volume of production of tourist services.

This research was performed within the 
framework of the R\&D "Prospective Ways to Improve the International Competitiveness of
Regional Enterprises on an Innovative Basis" (No. DR 0114I005503).

\begin{abstract}
Introduction. Today, in a market economy, the search for ways to increase its competitiveness, as well as reserves for improving the quality of tourism services is becoming an urgent need for enterprises in the tourism industry of Ukraine.

The work of many modern researchers is devoted to studying the problems of improving the quality and competitiveness of services. However, there is a lack of practical methodological support for assessing the competitiveness of services.

The purpose of the article is to determine a methodological approach to assessing the competitiveness of enterprises in the tourism industry of Ukraine, its strengths and weaknesses, reserves for improving the quality of service.

The methods of synthesis and analysis, comparison and analogy, the method of expert and point evaluation were used.

Results. The study proposes a methodology for assessing the competitiveness of services in tourism enterprises. The algorithm of complex estimation of competitiveness of tourist services is formed, which consists of ten stages. Expert assessment methods and weights determine the position of specific tourism enterprises in the competitiveness of services.

Conclusions: Almost all serious marketing successes of tourism enterprises are based on the use of their own strengths against competitors' weaknesses. This gives the tourism enterprise: individual advantages in the market and the possibility of scientifically grounded positions with pre-planned research to evaluate the probable prospects of advantages in the market; identify specific priorities urgently; take appropriate measures to develop a strategy of neutralization in the market of strong competitors; in qualitative terms to increase the competitiveness of a particular type of services and the efficiency of the enterprise as a whole; carry out work to improve the motivation and skills of the staff of the tourism company. Despite the financial, economic and sociopolitical difficulties of recent years, the tourism industry of Ukraine is trying to consistently increase the volume of tourism services.
\end{abstract}

\title{
Список літератури:
}

1. Большой экономический словарь / Под ред. А.Н. Азрилияна. - 5-е изд. - М.: ННЭ, 2002. -1280 с.

2. Восколович Н.А. Маркетинг туристичных услуг: учебник / Н.А. Восколович. - М.: ЮНИТИДАНА, 2011. - 207 c.

3. Дзахмишева Н.Ш. Методика оценки конкурентоспособности услуги в розничной торговой сети / Н.Ш. Дзашмишева / Маркетинг в России и за рубежом. - 2004. -№3 (4). - С. 93-107.

4. Дурович А. Маркетинговые исследования в туризме: уч.-практ. пособие / А. Дурович, Л. Анастасова. - М.: Новое знание, 2002, - 348 с.

5. Дядечко Л.П.Економіка туристичного бізнесу: навч. посібник / Л.П.Дядечко. - К.: ЦУЛ, 2007. $224 \mathrm{c}$.

6. Конкуренция, конкурентоспособность, рыночная конъюнктура: уч. пособие / Под ред. В.И. Дубницкого. - Днепропетровск: ГВУЗ «УГХТУ», 2016. - 400 с.

7. Криворотов В.В. Конкурентоспособность предприятий и производственных систем: уч. пособие / В.В. Криворотов, А.В. Калина, С.Е. Ерыпалов. - М.: ЮНИТИ-ДАНА, 2016. - 351 с.

8. Литвак Б.Г. Экспертные технологии в управлении: уч. пособие / Б.Г. Литвак. - М.: Дело, 2004. $400 \mathrm{c}$.

9. Маркетинг в туризме: уч. пособие / Сост. Д.Ш. Смирнова. - М.: КНОРУС, 2016. - 200 с.

10. Менеджмент туристичної індустрії: навч. посібник / За ред. І.М. Школи. - Чернівці: Книги XXI, 2005. - $596 \mathrm{c}$.

11. Моисеева Н.К. Маркетинг в турбизнесе: учебник / Н.К. Моисеева. - М.: Финансы и статистика, 2009. - 494 c.

12. Програма розвитку туризму та курортів в Одеській області на 2017-2020 pp. Рішення обласної ради № 285 - VII від 23.12.2016 p. [Электронный ресурс]. - Режим доступу: http://oda.odessa.gov.ua.

13. Удалова И.Б. Менеджмент в туристической индустрии: уч. пособие / И.Б. Удалова, Н.М. Удалова, Е.А. Машинская. - М.: Дашков и К, 2016. - 256 с.

14. Экономическая безопасность и конкурентная разведка: уч. пособие / Под ред. В.И. Захарченко. - Одеса: Атлант, 2017. - 519 с. 


\section{References:}

1. The big economic dictionary / Pod red. A.N. Azriliyana. - 5-e izd. - M.: NNE, (2002). - 1280 s. [in Russian].

2. Voskolovich N.A. (2011). Marketing of tourist services / N.A. Voskolovich. - M.: YuNITI-DANA, 207 s. [in Russian].

3. Dzakhmisheva N.Sh. (2004). Methodology for assessing the competitiveness of services in the retail trade network / N.Sh. Dzashmisheva / Marketing v Rossii i za rubezhom. - №3 (4). - S. 93-107. [in Russian].

4. Durovich A.( 2002). Marketing research in tourism / A. Durovich, L. Anastasova. - M.: Novoe znanie, - 348 s. [in Russian].

5. Diadechko L.P. (2007). Economics of Tourism Business: educ. manual / L.P.Diadechko. - K.: TsUL,224 s. [in Ukrainian].

6. Competition, competitiveness, market conditions / Pod red. V.I. Dubnitskogo. (2016). Dnepropetrovsk: GVUZ «UGKhTU», - 400 s. [in Russian].

7. Krivorotov V.V. (2016). Competitiveness of enterprises and production systems / V.V. Krivorotov, A.V. Kalina, S.E. Erypalov. - M.: YuNITI-DANA, - 351 s. [in Russian].

8. Litvak B.G. (2004). Expert technologies in management / B.G. Litvak. - M.: Delo. - 400 s. [in Russian].

9. Marketing in tourism / Sost. D.Sh. Smirnova. - M.: KNORUS, (2016). - 200 s. [in Russian].

10. Menedzhment turistichnoï industriï: navch. posibnik / Za red. I.M. Shkoli. - Chernivtsi: Knigi - KhKhI, (2005). - 596 s. [in Russian].

11. Moiseeva N.K. (2009). Marketing in the tourist industry / N.K. Moiseeva. - M.: Finansy i statistika. 494 s. [in Russian].

12. Program of development of tourism and resorts in the Odessa region for 2017-2020. Decision of the regional council № 285-VII] (2016, December) [Эlektronnыi resurs]. - Rezhym dostupu: http://oda.odessa.gov.ua. [in Ukrainian].

13. Udalova I.B. (2016) Management in the tourism industry / I.B. Udalova, N.M. Udalova, E.A. Mashinskaya. - M.: Dashkov i K. - 256 s. [in Russian].

14. Economic security and competitive intelligence / Pod red. V.I. Zakharchenko. - Odesa: Atlant, (2017). -519 s. [in Russian].

\section{Посилання на статтю:}

Zakharchenko V.I. Methodology for assessing the competitiveness of services in the tourism industry / V.I. Zakharchenko, T.K. Metil, L.M. Soroka // Economics: time realities. Scientific journal.-2020. - № 1 (47). - P. $27-$ 37. - Retrieved from https://economics.opu.ua/files/archive/2020/No1/27.pdf.

DOI: 10.15276/ETR.01.2020.4. DOI: 10.5281/zenodo.3967371.

\section{Reference a Journal Article:}

Zakharchenko V.I. Methodology for assessing the competitiveness of services in the tourism industry / V.I. Zakharchenko, T.K. Metil, L.M. Soroka // Economics: time realities. Scientific journal.- 2020. - № 1 (47). - P. $27-$ 37. - Retrieved from https://economics.opu.ua/files/archive/2020/No1/27.pdf.

DOI: 10.15276/ETR.01.2020.4. DOI: 10.5281/zenodo.3967371. 